\title{
Pemberdayaan Masyarakat Dalam Mendukung Keberhasilan Pemberian Asi Ekslusif
}

\author{
Reni Sulistyowati, Septi Kurniawati, Yeni Andriani \\ Program Studi D.III Kebidanan Akademi Kesehatan RUSTIDA \\ rennysulistyowati87@gmail.com
}

\begin{abstract}
Abstrak
Menyusui merupakan aspek yang sangat penting untuk kelangsungan hidup bayi guna mencapai tumbuh kembang bayi/anak yang optimal. Bayi yang mendapatkan ASI Ekslusif selama enam bulan secara signifikan menurunkan resiko terjadinya diare dan menurunkan resiko ISPA jika dibandingkan bayi yang tidak mendapat ASI Ekslusif. Puskesmas Kedung Rejo mempunyai cakupan ASI yang masih rendah meskipun secara geografis Puskesmas ini berada di wilayah kecamatan Muncar sebagai wilayah penghasil ikan laut terbesar nomor dua di Indonesia. Melihat kondisi tersebut, seharusnya cakupan ASI Eklsusif memenuhi target karena sumber makanan yang baik untuk ibu menyusui sudah tersedia. Namun, pada kenyataannya cakupan ASI Ekslusif di wilayah Puskesmas tersebut masih rendah. Untuk membantu meningkatkan pencapaian target ASI Ekslusif serta mengurangi penurunan angka kematian bayi, balita dan kematian ibu, Pemerintah Kabupaten Banyuwangi mencanangkan Kelompok Pendukung ASI. Untuk membatu pencanangan tersebut, kami berupaya memotivasi masyarakat untuk memberikan ASI Ekslusif. Salah satu permasalahan yang dialami di wilayah kerja Puskesmas Kedungrejo Muncar guna meningkatkan cakupan ASI adalah masih terbatasnya motivator ASI. Untuk itu, program pengabdian ini fokus pada upaya memaksimalkan pelatihan motivator ASI di wilayah kerja Puskesmas Kedungrejo Muncar.
\end{abstract}

Kata kunci: ASI Eksklusif, Motivator ASI

\begin{abstract}
Breastfeeding is a very important aspect for the survival of the baby in order to achieve optimal growth of the baby/child. Infants who are exclusively breastfed for six months significantly reduce the risk of diarhea and reduce the risk of ISPA when compared to infants who are not exclusively breastfed. The Kedung Rejo Community Health Center has a low coverage of breast milk even though geographically the Community Health Center is located in the Muncar sub-district as the second largest sea fish producing region in Indonesia. Seeing these conditions, the scope of exclusive breastfeeding should meet the target because good food sources for breastfeeding mothers are available. However, in reality the coverage of exclusive breastfeeding in the Puskesmas area is still low. To help increase the achievement of the exclusive ASI target and reduce the reduction in infant, under-five and maternal mortality rates, the Banyuwangi District Government has launched an ASI Support Group. To help with the proclamation, we try to motivate people to give exclusive breastfeeding. One of the problems experienced in the working area of the Kedungrejo Muncar Community Health Center in order to increase the coverage of ASI is the limited motivation of ASI. For this reason, this service program focuses on maximizing ASI motivator training in the working area of the Kedungrejo Muncar Community Health Center.
\end{abstract}

Keywords: ASI Exlusive, ASI Motivator 


\section{PENDAHULUAN}

World Health Organization dalam penelitiannya menunjukan bahwa ASI mengandung semua nutrisi yang diperlukan bayi untuk bertahan hidup pada 6 bulan pertama, dari hormon antibodi hingga antioksidan. Berdasarkan hal tersebut, WHO dan menteri kesehatan RI No.450/MENKES/IV/2004 mengubah ketentuan mengenai ASI esklusif yang semula 4 bulan menjadi 6 bulan (Riksani, 2012). Pemberian ASI esklusif ini juga menurunkan angka mortalitas dan morbiditas, mengoptimalkan petumbuhan bayi, membantu perekembangan kecerdasan anak dan meningkatkan ikatan antara ibu dan bayi. Manfaat lainnya juga didapatkan oleh sang ibu, yaitu untuk mempercepat pengembalian berat badan seperti sebelum ibu hamil dan juga ada manfaat kontrassepsi alami jika dilakukan dengan tepat sehingga membantu untuk memperpajang atau menjag a jarak kehamilan (Arora et al, 2000 dalam Fikawati, 2010).

Berdasarkan laporan dari Puskesmas diwilayah Dinas Kesehatan Banyuwangi, bahwa jumlah target sasaran ASI ekslusif pada tahun 2016 sebanyak $71 \%$ yang meliputi bayi berusia $0-6$ bulan menurut jenis kelamin lakilaki dan perempuan. Sebenarnya capaian ASI Ekslusif pada tahun tersebut sudah mengalami peningkatan dibandingkan tahun sebelumnya, namun angka ini masih jauh apa yang menjadi target dari Jawa Timur yaitu 100\% ASI Ekslusif. Data dari Dinas Kesehatan Kabupaten Banyuwangi menunjukan bahwa wilayah kerja Puskesmas Kedungrejo mempunyai cakupan yang masih tergolong rendah. Walaupun secara geografis Puskesmas ini berada di wilayah kecamatan Muncar. Dimana, Muncar merupakan penghasil ikan laut terbesar no dua di Indonesia. Melihat kondisi tersebut seharusnya cakupan ASI Eklsusif memenuhi target, karena sumber makanan yang baik untuk ibu menyusui sudah tersedia. Namun, pada kenyataannya cakupan ASI Ekslusif di wilayah Puskesmas tersebut masih rendah. Untuk membantu meningkatkan pencapaian target ASI Ekslusif serta mengurangi penurunan angka kematian bayi, balita dan kematian ibu, Pemerintah Kabupaten Banyuwangi mencanangkan Kelompok Pendukung ASI, dalam membatu pencanangan tersebut kami berupaya melakukan motivasi kepada masyarakat untuk memberikan ASI Ekslusif.

Sesuai dengan standar baku emas dalam pemberian makanan bayi dan anak dimulai dari Inisiasi Meyusui Dini (IMD), ASI Ekslusif selama enam bulan diteruskan dengan pemberian ASI sampai dengan dua tahun disertai pemberian Makanan Pendamping ASI (MP ASI) dengan gizi seimbang untuk mendukung pertumbuhan dan perkembangan fisik serta mental anak yang optimal. Dalam rangka mewujudkan hal tersebut dibentuk Kelompok Pendukung ASI. Kelompok Pendukung ASI Ekslusif merupakan kelompok pendukung ibu yang menyusui untuk dapat menyusui bayinya secara Ekslusif. Seorang ibu yang memiliki pengalaman menyusui akan memberikan informasi, pengalaman dan menawarkan bantuan kepada ibu lainnya dalam kondisi saling percaya dan menghargai. Peserta kelompok pendukung ASI Ekslusif ini terdiri dari kader kesehatan, ibu yang berhasil menyusui secara Eklsusif, suami dan keluarga ibu menyusui. Sebenarnya dari Dinas Kesehatan sudah pernah dilakukan pelatihan tentang Konselor ASI maupun Motivator ASI, namun baik Konselor ASI dan Motivator 
yang dilatih adalah bidan yang ada diwilayah kerja puskesmas yang diwakili oleh satu orang bidan setiap puskesmas. Namun pelatihan ini hanya sebatas sampai di bidan dan tidak dilanjutkan kepada kader dan masyarakat sekitar, sehingga kegiatan sosialisasi mengenai ASI ekslusif tidak maksimal dikarenakan jumlah SDM yang masih terbatas dan hal ini berdampak pada cakupan ASI Ekslusif yang tidak kunjung tercapai.

\section{MATERI DAN METODE}

Kegiatan ini dilaksanakan selam 4 bulan terhitung sejak Juli 2018 - Oktober 2018 di Wilayah kerja Puskesmas Kedungrejo Muncar. Langkah - langkah kegiatan yang dilaksanakan adalah sebagai berikut:

2.1 Persiapan program

Persiapan program pemberdayaan kader dalam meningkatkan keberhasilan ASI di awali dengan melakukan pendekatan kepada pihak puskesmas sekaligus survey data mengenai keberhasilan menyusui di wilayah kerja Puskesmas Kedungrejo Muncar dan data mengenai jumlah kader yang aktif melakukan kegiatan Kelompok Pendukung ASI. Dalam kegiatan ini diketahui bahwa jumlah kader poyandu kesehatan ada sekitar 80 orang yang aktif, akan tetapi untuk kader yang sudah mengikuti pelatihan motivator ASI hanya ada 1 orang di wilayah kerja Puskesmas Kedungrejo Muncar. Dalam rangka membantu meningkatnya keberhasilan menyusui maka di rencanakan akan diberikan pelatihan kepada 30 orang kader pposyandu yang bersedia untuk menjadi motivator ASI yang mana kegiatannya akan dilaksanakan di AULA Puskesmas Kedungrejo Muncar Banyuwangi.

2.2 Persiapan alat

Persiapan alat dan bahan yang dibutuhkan dalam kegiatan ini diawali dengan sosialisasi, penyusunan modul motivator ASI, laptop, LCD, sond sistem, mix dan alat peraga menyusui yang benar terdiri dari panthom bayi, model payudara, handuk, baby oil, waslap dan baskom.

2.3 Pelaksanaan program

Pelaksanaan kegiatan pemberdayaan ini diawali dengan sosialisasi melalui penyebaran undangan kepada calon motivator ASI dan dilanjutkan dengan pelatihan mengenai Pentingnya ASI Ekslusif yang dilaksanakan di AULA Puskesmas Kedungrejo Muncar yang diikuti oleh 30 orang kader posyandu, 1 orang penanggung jawab program KIA Puskesmas Kedungrejo Muncar. Kegiatan dijalankan oleh TIM Akademi Kesehatan Rustida yang terdiri dari dosen dan mahasiswa. Metode yang diterapkan meliputi ceramah, demonstrasi dan redemonstrasi. Materi yang disampaikan kepada kader posyandu yang berkenan menjadi motivator ASI adalah 1) Konsep motivator ASI dan kelompok Pendukung ASI, 2) Konsep inisiasi menyusui dini 3) Konsep ASI ekslusif 4) konsep tehnik menyusui dan senam payudara 5) praktek menyusui dan senam payudara.

2.4 Pendampingan, Monitoring dan evaluasi

Pendampingan yang dilaksanakan secara langsung adalah pelatihan yang dilaksanakan dengan memberikan materi mengenai pentingnya ASI, teknik menyusui dan senam payudara, dengan harapan kegiatan ini bermanfaat 
untuk mempermudah dan melancarkan pemberian informasi oleh motivator ASI kepada masyarakat luas guna meningkatkan pengetahuan dan keberhasilan menyusui secara Eksllusif. Untuk memastikan kegiatan berjalan dengan baik maka dilakukan evaluasi secara langsung kepada peserta pelatihan guna mempraktekan tehnik menyusui yang benar dan senam payudara. Selanjutnya evaluasi dilakukan melalui 2 cara :

a. Evaluasi jangka pendek yang dilakukan dengan memberikan beberapa pertanyaan kepada peserta pelatihan. Tujuan dari evaluasi ini adalah untuk mengatahui ada tidaknya peningkatan pengetahuan peserta pelatihan mengenai pentingnya ASI.

b. Evaluasi jangka panjang dilakukan sebulan kemuadian melalui kegiatan poyandu di wilayah kerja Puskesmas Kedungrejo Muncar dan melihat langsung bagaimana motivator mengajarkan kepada ibu hamil, ibu menyusui dan ibu nifas mengenai pentingnya ASI, cara menyusui yang benar dan senam payudara.

\section{HASIL DAN PEMBAHASAN}

Program pelatihan ini dilakukan secara terstruktur dengan jumlah peserta 30 orang kader kesehatan dan diawasi langsung oleh penanggung jawab program KIA dan bidang gizi.

3.1 Penyampaian materi

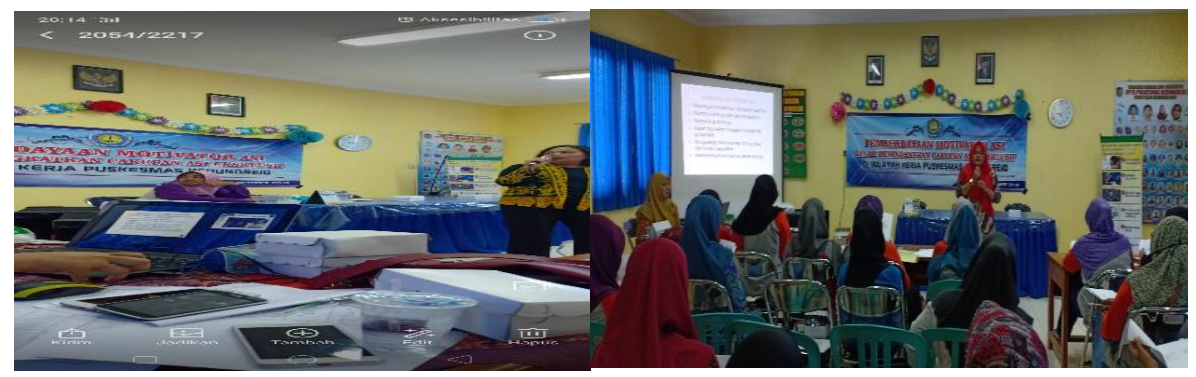

Gambar 1. Kegiatan pemberian materi ASI ekslusif, tehnik menyusui dan senam payudara

3.2 Praktek menyusui

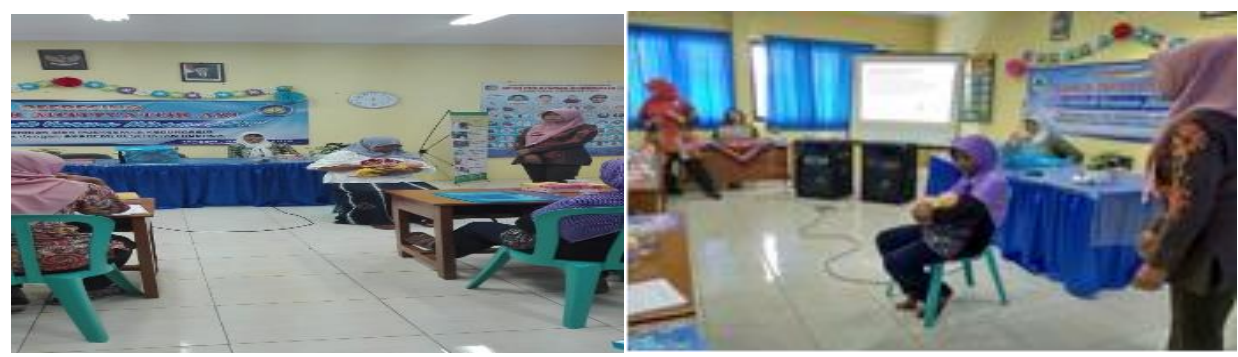

Gambar 2. Teknik menyusui yang benar 


\subsection{Hasil dan Pembahasan}

1. Pengetahuan motivator ASI tentang ASI ekslusif

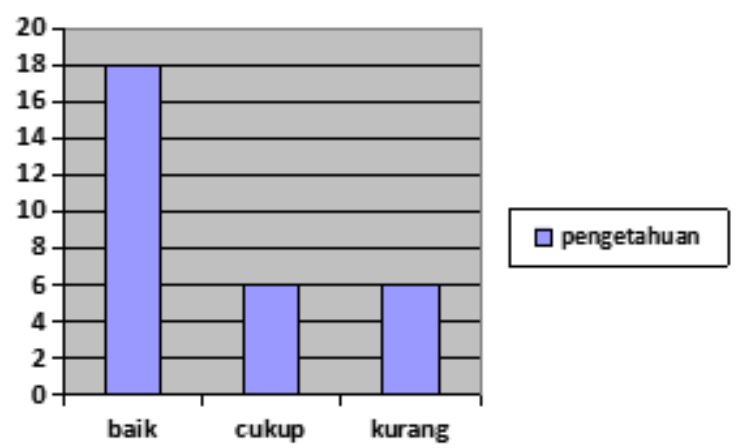

Gambar 3. Menunjukan bahwa pengetahuan motivator tentang ASi ekslusif sebagian besar 60\% berpengetahuan baik tentang ASI ekslusif dibandingkan dengan yang berpengetahuan sedang 20\% dan kurang 20\%.

2. Pengetahuan motivator ASI tentang tehnik menyusui yang benar

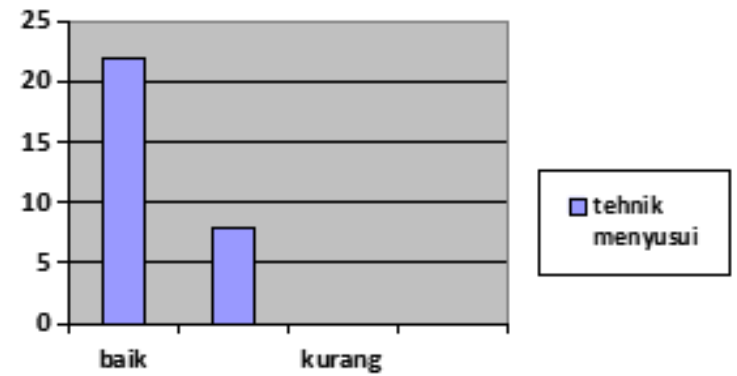

Gambar 4. Menunjukan bahwa pengatahuan motivator tentang tehnik menyusui yang benar sebagian besar $73 \%$ berpengetahuan baik dibandingkan dengan yang berpengetahuan sedang $27 \%$.

3. Pengetahuan motivator ASI tentang senam payudara

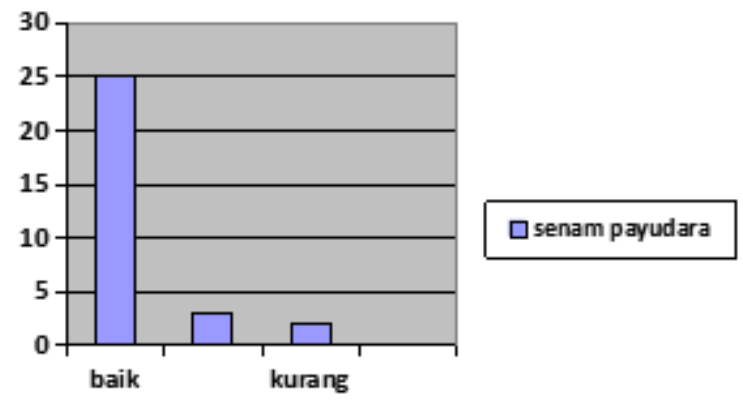

Gambar 5. Menunjukan bahwa pengatahuan motivator tentang senam payudara sebagian besar $83 \%$ berpengetahuan baik dibandingkan dengan yang berpengetahuan kurang $6 \%$. 
4. Kemampuan motivator ASI mempraktekan tehnik menyusui dan senam payudara

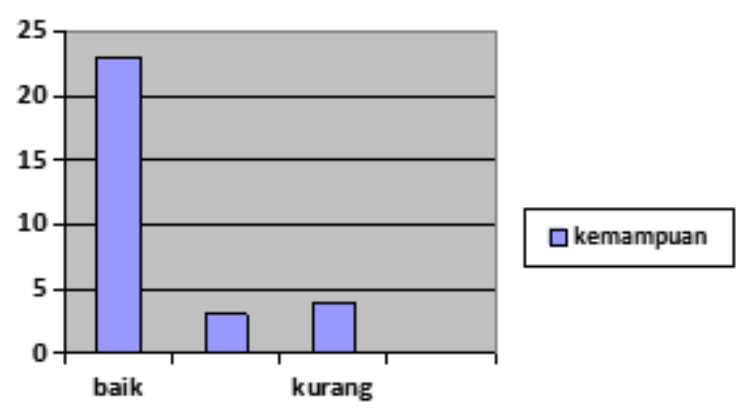

Gambar 6. Menunjukan bahwa kemampuan motivator tentang tehnik menyusui dan senam payudara sebagian besar $76.6 \%$ sudah baik dibandingkan dengan yang belum mampu mempraktekan 13\%.

\section{Pembahasan}

Berdasarkan pengetahuan motivator tentang ASI ekslusif, tehnik menyusui, dan senam payudara sebagian besar pengetahuannya sudah tergolong dalam kategori baik. Selain itu, dari segi praktek atau kemampuan motivator mempraktekan teknik menyusui dan senam payudara juga sudah sebagian besar tergolong dalam kategori baik atau mampu, walaupun masih ada 3 orang / $13 \%$ yang masuk dalam kategori kurang dikarenakan motivator belum pernah menyusui.

Pengetahuan merupakan salah satu komponen yang mendukung terjadinya perilaku akan tetapi dalam kenyataan dilapangan, angka keberhasilan menyusui masih tergolong rendah, Hal ini disebabkan beberapa faktor. Diantaranya, masih tingginya jumlah ibu yang memberikan susu formula diawal kehidupan bayi dengan berbagai alasan seperti ASI belum keluar sehingga para ibu takut bila bayinya kelaparan dan mengalami kuning, putting susu pecah yang jika dipakasakan ada keyakinan bayi dapat meninggal, masih kurangnya pemberian informasi khususnya melalui media massa mengenai pentingnya ASI. ASI merupakan makanan terbaik bayi, yang secara luas mampu membantu pemerintah untuk menurunkan angka kesakitan bahkan kematian pada ibu dan bayi jika setiap bayi yang lahir mendapatkan ASI secara ekslusif. 


\section{Kesimpulan}

\section{KESIMPULAN}

Pemberdayaan masyarakat dalam mendukung keberhasilan pemberian ASI eksklusif memberikan dampak positif bagi kesehatan Ibu dan Anak seperti menurunnya angka kematian bayi, balita dan kematian ibu. Hal tersebut ditunjukan melalui Indikator berikut ini :

1. Peningkatan pengetahuan motivator tentang ASI, tehnik menyusui dan senam payudara lebih baik setelah diberikan pelatihan atau refresing.

2. Peningkatan kemampuan motivator tentang tehnik menyusui dan senam payudara lebih baik setelah diberikan pelatihan atau refresing.

\section{Saran}

Keberhasilan pelaksanaan kegiatan pemberdayaan masyarakat dalam mendukung keberhasilan pemberian ASI eksklusif dapat ditingkatkan melalui :

1. Perlu adanya evaluasi atau tindak lanjut untuk mengetahui dilakukannya sosialisasi kepada masyarakat luas serta mengevaluasi adanya peningkatan keberhasilan menyusui.

2. Perlu dilakukannya refresing setidakanya 6 bulan sekali guna mengevaluasi pengetahuan dan kemampuan motivator sekaligus update informasi mengenai ASI.

\section{DAFTAR PUSTAKA}

Dinas Kesehatan Kabupaten Banyuwangi. 2015. Rencana Aksi Daerah Kabupaten Banyuwangi Layak Anak Tahun 2013-2015. Dinas Kesehatan Kabupaten Banyuwangi. Banyuwangi.

Fikawati S dan Syafiq A. 2010. Kajian Implementasi dan Kebijakan Air Susu Ibu Ekslusif dan Inisiasi Menyusui Dini di Indonesia. Makara Kesehatan. Vol 14 (1). Halaman: $17-24$.

Laporan Tahunan Puskesmas Tembokrejo. (2016). Laporan Tahunan Program Puskesmas Tembokrejo Tahun 2016. Banyuwangi.

Mihrshahi, S., Webb, K., Almqvist, C., Kemp, A. (2008). Adherence to Allergy Prevention Recommendations in Children with a Family History of Asthma. Pediatric Allergy and Immunology, 19, 355-362.

Riksani R. 2012. Keajaiban ASI (Air Susu Ibu). Jakarta. Dunia Sehat. 